\title{
PEMIKIRAN ABDULLAH AN-NA'IM TENTANG TEORI EVOLUSI SYARI'AH (NASAKH) DAN RELEVANSINYA DENGAN METODE ISTINBATH HUKUM ISLAM
}

\author{
Dwi Sagita Akbar \\ LAIN Bukittinggi,dwisagitaakbar@gmail.com \\ Afifi Fauzi Abbas \\ IAIN Bukittinggi, afififauriabbas@gmail.com
}

Diterima: 16 Januari 2020

Direvisi : 07 Juli 2020

Diterbitkan: 9 Juli 2020

\begin{abstract}
In order to offer a transformative discourse Abdullah Ahmad An-Na'im build a method be called with the evolution of Shari'ah (abrogated). According to him the method can respond to contemporary issues at this time. Because he assumed that abrogating is one of the principal methods and has a wide and high complexity in theology and fiqh (jurisprudence) of Islam. He tries to deconstruct abrogated method and also some methods of ijtihad that had been considered settled by the classical scholar. Abdullah Ahmad An-Na'im radically have done repeated studies against the epistimologi Islamic law as well as the mereformulasi return and customize it with the standard of human rights as well as international law as a benchmark. The method developed by Abdullah Ahmad An-Na'im, he stated three important things that need to be done to realize the abrogating. Text, values of humanity, and logic. He also overestimated human rights, so that a text (paragraph) may be enforced in accordance with human rights. In order to answer the legal issues of contemporary Islam.
\end{abstract}

Keywords: An-Na'im, Shariah Evolution.

\begin{abstract}
Abstrak
Dalam rangka menawarkan wacana transformatif Abdullah Ahmad An-Na im membangun sebuah metode yang ia sebut dengan evolusi syari ah (nasakh). Menurutnya metode tersebut dapat menjawab persoalanpersoalan kontemporer saat ini. Karena ia beranggapan metode pokok dalam teologi dan fiqh (yurisprudensi) Islam adalah nasakh, dikarenakan nasakh memiliki kompleksitas yang luas dan tinggi dalam persoalan teologi dan fiqh. Ia mencoba untuk. mendekonstruksi metode nasakh dan juga beberapa metode ijtihad yang selama ini telah dianggap mapan oleh ulama klasik. Abdullah Abmad An-Na im secara radikal telah melakukan kajian ulang terhadap epistimologi hukum Islam serta mereformulasi kembali dan menyesuaikannya dengan standard hak asasi manusia serta bukum international sebagai tolak ukur. Metode yang dibangun oleh Abdullah Ahmad An-Na im, ia menandaskan tiga hal penting yang perlu dilakukan untuk merealisasikan nasakh tersebut yaitu. Teks, nilai-nilai kemanusian, dan logika. Ia juga terlalu mengagungkan hak asasi manusia, sehingga sebuah teks (ayat) dapat diberlakukan apabila sesuai dengan hak asasi manusia. Dalam rangka menjawab permasalahan hukum Islam kontemporer.
\end{abstract}

Kata Kunci: An-Na im, Evolusi Syari ‘h.

\section{PENDAHULUAN}

Modernisasi atau pembaruan dalam Islam dipahami sebagai upaya dalam rangka menyelaraskan paham-paham keagamaan dalam Islam dengan berbagai perkembangan baru yang ditimbulkan oleh kemajuan ilmu pengetahuan dan teknologi modern dan juga tidak terlepas dari hukum-hukum Barat. Di sisi lain upaya yang dilakukan oleh para intelektual Islam dalam rangka memperbarui penafsiran, penjabaran dan cara-cara pelaksanaan ajaranajaran dasar dan petunjuk-petunjuk yang terdapat dalam Alquran dan hadis sesuai dan sejalan dengan perkembangan situasi dan 
kondisi masalah yang dihadapi juga disebut modernisasi Islam. ${ }^{1}$

Perkembangan serta perubahan secara cepat yang terjadi dalam masyarakat merupakan salah satu bentuk pengaruh dari pesatnya perkembangan ilmu pengetahuan dan teknologi. Sehingga banyak dijumpai persoalan-persoalan yang terjadi di tengahtengah masyarakat khususnya umat Islam yang ketentuan hukumnya secara eksplisit tidak dapat ditemui dalam Alquran maupun hadis. Oleh karena itu dalam rangka memberi kepastian hukum terhadap persoalan-persoalan tersebut, maka Islam memberikan jalan kepada umatnya untuk menggunakan akal pikirannya secara sungguh-sungguh, cermat, dan teliti agar dapat menetapkan ketentuan dengan tepat dan benar. Jalan tersebut dalam ushul figh disebut ijtihad. $^{2}$

Pada dasarnnya ijtihad berguna dalam penyelesaian peristiwa-peristiwa yang menyangkut berbagai aspek kehidupan manusia, terutama untuk menjawab persoalan yang tidak tegas dijelaskan oleh nas. Menurut Router Garaudy, tantangan yang dihadapi umat Islam untuk sekarang ini dapat dikategorikan kepada dua bentuk, taklid kepada barat dan taklid kepada masa lalu. Taklid kepada barat muncul disebabkan ketidakmampuan dalam membedakan antara modernisasi dan cara hidup Barat; sedangkan taklid kepada masa lalu muncul karena ketidakmampuan dalam membedakan antara syari at yang merupakan wahyu Allah dan pandangan fuqaha masa lalu tentang syari`at itu. ${ }^{3}$

Menurut Bollouta sebagaimana yang dikutip Aksin Wijaya, terdapat tiga kecendrungan wacana yang berkembang di

\footnotetext{
1 Rifaat Syauqi An-Nawawi, Rasionalitas Tafsir Mubammad Abduh, Kajian Masalah Aqidah Dan Ibadat (Jakarta: Paramadina, 2002). h. 5

2 Syamsul Bahri, Metodologi Hukum Islam (Yogyakarta: Teras, 2008). h. v

${ }^{3}$ Atang Abd. Hakim and Jaih Mubarok, Metodologi Studi Islam (Bandung: PT Remaja Rosdakarya, 2000). h. 107
}

kalangan pemikir hukum Islam berkenaan dengan tradisi dan budaya vis a vis modernitas.

Pertama, kelompok yang menginginkan agar dunia Arab dapat lepas dari tradisi masa lalunya, karena mereka beranggapan tradisi masa lalu tidak lagi memadai dan tidak relevan bagi kehidupan kontemporer. Kelompok ini dikenal sebagai kelompok yang menawarkan wacana transformatif di mana mereka cendrung memiliki pemikiran yang liberal. Seperti Abdullah Ahmad An-Na`im, Salamah Musa, Zaki Najib Mahmud, dan lain sebagainya.

Kedua, kelompok yang menginginkan sikap akomodatif, dengan mereformasi tradisi yang selama ini digelutinya. Kelompok ini dikenal sebagai kelompok yang menawarkan wacana reformatif, seperti Mohammed Arkoun, Hasan Hanafi, Fazlurrahman, dan lain sebagainya.

Ketiga, kelompok ini disebut idealis totalistik. Mereka menginginkan agar dunia Arab kembali kepada Islam murni, khususnya aliran salaf dengan slogan kembali kepada Alquran dan hadis. ${ }^{4}$

Kelompok-kelompok tersebut telah melahirkan berbagai macam metode dalam rangka menawarkan wacana transformatif dan reformatif. Salah satu yang menarik untuk dilihat adalah wacana transformatif yang disajikan oleh Abdullah Ahmad An-Na im. Ia menawarkan sebuah metode evolusi syari ah (nasakh) yang menurutnya dapat menjawab persoalan-persoalan kontemporer saat ini. Karena ia beranggapan bahwa nasakh merupakan salah satu metode yang pokok, serta

\footnotetext{
${ }^{4}$ Aksin Wijaya, Menggugat Otensitas Wabyu Tuban; Kritik Atas Nalar Tafsir Gender (Yogyakarta: Safiria Insania Press, 2004); Fathor Rahman, 'Pencarian Format Baru Syari ah Di Era Modern (Kajian Atas Konsep Reformasi Syari ah Dalam Dekonstruksi Syariah-Nya Abdullah Ahmed An-Na 'im)', Jurnal Institut Agama Islam Ibrabimy Situbondo 5, no. 1 (2013): 159.
} 
memiliki kompleksitas yang luas dan tinggi dalam teologi dan fiqh (yurisprudensi) Islam. ${ }^{5}$

Berkaitan dengan hal tersebut penulis akan menyusun kerangka berfikir An-Na im kemudian melihat relevansi pemikiran tersebut dengan metode istinbath hukum Islam. Sehingga teori yang disajikan oleh Abdullah An-Na im dapat memberikan peran yang signifikan dalam menjawab persoalanpersoalan baru yang muncul di era kontemporer.

\section{BIOGRAFI ABDULLAH AN-NA'IM}

Abdullah Ahmad An-Na im dikenal sebagai ahli hukum dan aktivis yang berasal dari Sudan. Dalam beberapa catatan menjelaskan bahwa Abdullah Ahmad An-Na im dilahirkan pada tanggal 19 November 1946 tepatnya di desa yang disebut al-Maqawier, yang terletak di tepi barat Nile $200 \mathrm{~km}$ dari Utara Khartoum. Abdullah Ahmad An-Na im merupakan anak pertama dari sebelas bersaudara yang berasal dari pasangan Ahmed An-Na im dan Aisha alAwad Osman. Abdullah Ahmad An-Na`im memiliki enam saudara laki-laki dan empat saudara perempuan, tetapi dua dari saudara perempuannya telah meninggal di masa kanakkanak. Ayahnya Ahmed hanya belajar Alquran, menulis dan membaca di madrasah, dan tidak pernah mendapat pendidikan formal lagi di atasnya dan ibunya buta huruf. ${ }^{6}$

Ahmed An-Na im, ayah Abdullah Ahmad An-Na im mulai bekerja sebagai petani kampung pada usia sebelas tahun. Ia kemudian pergi untuk bekerja sebagai pelayan di Angkatan pertahanan Sudan di kota Shendi, melewati Nile dari al-Maqawir. Akhirnya ia menjadi anggota prajurit biasa pada usia 17

\footnotetext{
${ }^{5}$ Abdullah Ahmad An-Na im terj; Ahmad Suaid dan Amirrudin Arrani, Dekonstruksi Syari ah (Yogyakarta: LKIS, 1994). h. 111

6 Moh Dahlan, Abdullah Ahmad An-Naim Epistimologi Hukum Islam (Yogyakarta: Pustaka Pelajar, 2009). h. 42

${ }^{7}$ Dahlan. h. 43
}

tahun dan karirnya sebagai prajurit terus naik pengkatnya hingga ia mengundurkan diri sebagai brigadier General tahun 1973.

Sebagai sarjana Islam yang diakui secara internasional, ia terkenal sangat aktif dalam bidang hak asasi manusia dalam persfektif internasional serta hak asasi manusia dalam perspektif lintas budaya. Kesungguhan Abdullah Ahmad An-Naim dalam memperjuangkan hak asasi manusia di dunia international dapat dilihat dalam keterlibatannya di berbagai lembaga-lembaga hak asasi manusia international. Seperti aktifnya Abdullah Ahmad An-Na im dalam lembaga The International Council on Human Rights Policy di Genewa, Swiss. Selain itu ia juga aktif di lembaga International Advisory Council of the International Center for the Legal Protection of Human Ribts (Interrights), London. ${ }^{8}$

Abdulah Ahmad An-Na im menyelesaikan studi S1-nya di Universitas Khartoum Sudan. Saat kuliah di Universitas Khartoum, Abdullah ahmad An-Na im mengambil konsentrasi di fakultas hukum khususnya di jurusan hukum pidana. Pendidikan S1-nya ini ia selesaikan pada tahun 1970 dengan gelar LL.B. ${ }^{9}$

Pada saat yang bersamaan ketika Abdullah Ahmad An-Na`im masih menyandang status sebagai mahasiswa, ia ikut bergabung dengan sebuah organisasi yang dipimpin oleh Mahmoud Thaha. Pada saat itu organisasi tersebut dikenal dengan The Republican Brotherbood. Dia tergolong pribadi yang antusias untuk menghadiri kuliah yang disampaikan oleh Mahmoud Thaha dan juga sering bergabung dalam diskusi-diskusi yang dilakukan di kediaman pribadi Mahmoud

8 Muhyar Fanani, Abdullab Ahmad An-Naim; Paradigma Baru Hukum Publik Islam, Dalam A. Khodri Shaleh, Pemikiran Islam Kontemporer (Yogyakarta: Jendela, 2003). h. 4

9 Abdullah Ahmad An-Na`im, Toward an Islamic Reformation; Civil Liberties, Human Right and International Law (Yogyakarta: LKiS, 1994). h. xi 
Thaha. ${ }^{10}$ Menjelang awal tahun 1968 Abdullah Ahmad An-Na im resmi menjadi anggota The Republican Brotherbood. ${ }^{11}$

Akan tetapi pada bulan Mei 1969 tepatnya ketika Pasca kudeta militer oleh Ja'far al-Numaery, Partai Republikan yang didirikan oleh Mahmoud Thaha kemudian berubah dari partai politik menjadi sebuah organisasi bernama Republican Brothers (al-Ikbwan alJumburiyyun). Anggota-anggota Republican Berothers yang masih menginginkan peran politis yang lebih sekular keluar menuju ke partaipartai lain. Sementara bagi mereka yang masih bersama Mahmoud Thaha, partai itu dialihkan dari partai politis menjadi semacam organisasi spiritual di bawah bimbingan Mahmoud Thaha. Republican Brothers kemudian menjadi musuh yang diakui terus terang oleh al-Ikhwan alMuslimin, sebuah gerakan Islamis noefundamentalis yang didirikan di Mesir. AlIkhwan al-Muslimin ingin membangun sebuah aturan yang totalitarian sebagaimana kejayaan teokrasi abad tengah, sebaliknya Mahmoud Thaha percaya kepada demokrasi, parlementer maupun presidensil, dan sosialisme Fabian. ${ }^{12}$

Pembubaran ini pada dasarnya dikarenakan adanya pertentangan antara organisasi Republican Brotherbood dengan kebijakan pemerintahan Numaery. Khususnya ketika Numaery memberlakukan hukum publik Islam di Sudan. Interpretasi Numaery sendiri atas ajaran Islam adalah dengan meletakkan hukum Islam sebagai pengatur ketatanegaraan dan karena itu, ia menerapkan hukumanhukuman yang terdapat dalam figh klasik, seperti sanksi pidana pendurian, rajam, sanksi

${ }_{10}$ Mahmoud Taha atau lebh dikenal Mahmoud Mohamed Taha merupakan aktivis yang dikenal aktif dalam gerakan kemerdekaan rakyat Sudan. Selain itu juga bekerja sebagai insinyur sipil dengan spesialis dalam bidang irigasi. Selain itu ia juga dikenal sebagai pembaharu Islam yang inovatif, beberapa menyebutnya heterodoks. Baca Charles Khurzman terj. Bahrul Ulum et.al, judul asli: Liberal Islam A Sourcebook, W acana Islam Liberal Pemikiran Islam Kontemporer Tentang Isu-Isu Global (Jakarta: Paramadina, 2001). h. 456 zina, dan sanksi pidana mati bagi orang yang murtad. Hukuman hukuman tersebut dirumuskan di bawah kendali otoritas Numaery sendiri tanpa melakukan konsultasi dengan Jaksa Agung dan Mahkamah Agung. Disinyalir bahwa hukuman tersebut diterapkan Numaery semata-mata untuk melindungi kekuasaannya. Beribu orang ditangkap dan diadili, layaknya pengadilan militer dengan menggunakan hukum Islam. ${ }^{13}$

Abdullah Ahmad An-Na im melanjutkan pendidikan S2-nya di Inggris, tepatnya di Universitas Cambridge. Di Universitas Cambridge ini Abdullah Ahmad An-Na`im mengambil konsentrasi di bidang hukum yang berkaitan dengan kebebasan sipil, hukum konstitusional, dan hukum perdata International. Pada tahun 1973 Abdullah Ahmad An-Na`im memperoleh gelar LL.M, dengan karya ilmiah yang berjudul Judicial Review of Administrative Action, The Law Relating to Civil Liberties, Constitutional Law, and Private International Law. Selain itu pada universitas yang sama dan juga pada tahun yang sama, Abdullah Ahmad An-Na im juga dapat menyelsaikan studi S-2 di bidang kriminologi dengan karya ilmiah Criminal Proses, Phenology, Sociology of Crime and Research Metodology. ${ }^{14}$

Sedangkan gelar Ph. D dalam bidang hukum diselesaikan oleh Abdullah Ahmad An$\mathrm{Na}$ `im di Universitas Edinburgh Skotlandia pada tahun 1976 dengan disertasi tentang Comparative Pre-Trial Criminal Procedur: English, Scotlish, U.S, and Sudanese Law (Perbandingan

11 An-Na im, Dekonstruksi Syari ah. h. xi

${ }^{12}$ Khalid Duran, 'An Alternatif to Islamism: The Evolutionary Thought of Mahmud Thaha, Cross Currents', Pro Quest Religion Winter 42 (1992): 453-67.

13 Mutawalli, 'Pembaharuan Hukum Islam Menimbang Pemikiran `Abd Al-Lah Ahmad Al-Na 'im', Ulumuna 12, no. 1 (2008): 113.

14 Muhammad Hefni, 'Desakan Sosiopolitik Munculnya Gagasan Evolusi Syari ah Oleh An-Na im', Al-Ahkam 8, no. 1 (2013): 104. 
Prosedur Pra Percobaan Hukum Inggris, Skotlandia, Amerika, Dan Sudan). ${ }^{15}$

Selain menjadi aktifis yang aktif di organisasi Republican Berotherbood, Abdullah Ahmad An-Na im juga aktif sebagai akademisi. Secara umum aktiftas yang dijalani Abdullah Ahmad An-Na`im sebagai akademisi, pada November 1976 Abdullah Ahmad An-Na im mengawali karirnya sebagai akademisi dengan menjadi pengajar di bidang hukum di universitas Khartoum. Karir yang dijalaninya sebagai dosen di universitas Khartoum khususnya di bidang hukum dan ini berakhir hingga Juni 1985. Tercatat Abdullah Ahmad An-Na im menjadi dosen di bidang hukum kurang lebih selama 9 tahun.

Secara bersamaan pada tahun 1979 Abdullah Ahmad An-Na im juga menjabat di bagian jurusan hukum publik di fakultas hukum Universitas Khartoum sebagai ketua jurusan hingga tahun 1985. Kurang lebih Abdullah Ahmad An-Na`im menjadi ketua jurusan hukum publik selama 6 tahun. ${ }^{16}$

Setelah berkontribusi dalam dunia pendidikan di Khartoum, pada tahun pada Agustus 1985 Abdullah Ahmad An-Na im diminta untuk menjadi profesor tamu di fakultas hukum UCLA, yang terletak di USA. Abdullah Ahmad An-Na im menjadi profesor tamu berlangsung hingga tahun $1987 .{ }^{17}$

Kemudian di bulan Agustus pada tahun 1988 Abdullah Ahmad An-Na`im juga menjadi profesor tamu Ariel F. Sallows yang bergelut khusus di bidang Hak Asasi Manusia di fakultas hukum University Saskatchewan di Kanada sampai tahun 1991. Antara Agustus

${ }^{15}$ Mahmud Muhammad Thaha, Syari at Demokratik, Terj. Nur Rachman, Judul Asli: Shariah Demokratik. (Surabaya: eLSAD, 1996). h. 4

16 Nabil Rahmad, Abdullah Ahmad An-Naim, diakses dari tulisan yang dimuat dalam https://www.slideshare.net/NabilRahmanElFaqir/abdu llah-ahmed-an-naim pada tanggal 04 Maret 2019

${ }^{17}$ Nabil Rahmad, Abdullab Abmad An-Na im..., diakses 04 Maret 2019 hingga Juni 1992, Abdullah Ahmad An-Na im juga menjadi profesor tamu di Olof Palme di fakultas hukum, University of Upshala, Swedia. ${ }^{18}$

Pada bulan Juli di tahun 1992 Abdullah Ahmad An-Na im diangkat menjadi sarjana tinggal untuk Timur Tengah dan Afrika Utara, dan ia ditempatkan di kantor The Ford Foundation Kairo Mesir. Ia menjadi sarjana tinggal ini di Kairo Mesir kurang lebih satu tahun. Pada bulan Juli tahun 1993 hingga April 1995 Abdullah Ahmad An-Na im diangkat menjadi direktur eksekutif pengawas Hak Asasi Manusia Afrika di Washington D.C. Pada bulan Juni 1995 Abdullah Ahmad An-Na im diangkat menjadi guru besar dan menjadi profesor di bidang hukum di Unversitas Emory, Afrika, G.A, Amerika Serikat. ${ }^{19}$

Pada bulan Februari 2009, Abdullah Ahmad An-Na im menerima gelar kehormatan doktor dari Universitas Chatoulique de Louvain (UCL Louvain-la Neuvu) dan dari Katholieke Universiteit Leuven (K.U. Leuven, Leuven), Belgium. Ia juga berperan sebagai Sarjana Hukum Global di Fakultas Hukum, Universitas Warwick, Inggris pada bulan September 2007 hingga Agustus 2010 dan menjadi Profesor Luar Biasa di Pusat Hak Asasi Manusia, Fakultas Hukum, Universitas Pretoria pada bulan Januari 2009 hingga Desember 2010. ${ }^{20}$

\section{KONSEP EVOLUSI SYARI'AH ABDULLAH AHMAD AN-NA'IM}

Abdullah Ahmad An-Na im menyajikan suatu metode yang dinggap sebagai

18 Nabil Rahmad, Abdullah Abmad An-Naim..., diakses 04 Maret 2019

19 Nabil Rahmad, Abdullah Ahmad An-Naim, diakses dari tulisan yang dimuat dalam https://www.slideshare.net/NabilRahmanElFaqir/abdu $\underline{\text { llah-ahmed-an-naim pada tanggal } 04}$ Maret 2019

${ }^{20}$ Abdullah Ahmad An-Na im, Islam And Human Rights; Selected Essay Of Abdullah Ahmad An-Na im, Diedit Oleb Mashood A. Baderin (London And New York: Routledge and Taylor Francis Group, 2016). h. xii 
metode ijtihad modern. Secara spesifik istilah untuk metode tersebut disebut dengan evolusi syari`ah (nasakb).

The evolution of Shari a simply its evolution by moving from one text (of the Qur an) to the other, from a text that is suibtable to govern in the seventh century, and was implemeted, to a text which was, at the time, too advanced and therefore had to be abrogated. ${ }^{21}$

Evolusi syari ah dipahami sebagai sebuah bentuk perpindahan dari suatu teks Alquran kepada teks Alquran yang lain. Abdullah Ahmad An-Na`im memberikan istilah evolusi dengan perpindahan dari satu teks yang dianggap pantas untuk mengatur abad ketujuh pada masa itu dan telah diterapkan, kepada suatu teks yang dibatalkan waktu itu disebabkan pada waktu itu terlalu maju.

Selanjutnya Abdullah Ahmad AnNa`im menjelaskan :

In this evolution we consider the rationale beyond the text. If a subsidiary verse, which used to overrule the primary verse in the seventh century, has served its purpose completely and become irrelevant for the new era, the twentieth century, the time has come for it to be abrogated and for primary verse to be enacted. In this was, the primary verse has its turn as the operative text in the twentieth century and becomes the basis of the new legislation. This is what the evolution of Shri a means. It is shifting from one text that served its purpose and was exhausted to another text that was postponed until its time came. Evolution is therefore nether unrealistic or premature, nor expressing a naive and immature opinion. It is merely shifting from one text to the other. ${ }^{22}$

Hal yang perlu dicatat dalam konsep Abdullah Ahmad An-Na im ia mengistilahkan ayat yang menjadi nasikh pada abad ketujuh adalah ayat tambahan dan ayat yang dimansukh adalah ayat utama. Sehingga Ia menjelaskan ketika ayat yang telah me-nasakh ayat utama

21 Abdullah Ahmad An-Naim, Toward an Islamic Reformation: Civil Liberties, Human Right, and International Law (New York: Syracuse University Press, 1990). h. 59 pada abad ketujuh karena dianggap relevan dan telah mefungsikan tujuannya secara sempurna. Sedangkan saat ini ayat tambahan tersebut tidak lagi relevan untuk kondisi kontemporer saat ini sehingga ayat tambahan tersebut perlu dihapuskan dan memberlakukan ayat utama (ayat yang di-mansukh) pada abad ketujuh. Menurutnya dengan cara ini, ayat utama kembali sebagai teks yang operatif pada abad kedua puluh dan menjadi basis legislasi yang baru. Inilah yang dimaksud dengan evolusi syari’ah. satu peralihan dari suatu teks yang telah mefungsikan tujuannya dan digantikan dengan teks lain yang ditunda hingga waktunya tepat. Oleh karena itu, evolusi bukan sesuatu yang tidak realistik atau prematur, bukan pula menunjukkan suatu pandangan yang naif dan mentah. Ia semata-mata hanyalah perolehan dari satu teks ke teks yang lain.

Dalam metode evolusi syari ahnya ini, ia menjabarkan aspek-aspek penting yang saling terkait. Yaitu persoalan Makkiyah dan Madaniyah, kemudian persoalan pemahaman nasakh yang selama ini dipahami oleh umat Islam.

Abdullah Ahmad An-Na im di sini lebih merepresentasikan konsep evolusi syariah (nasakh) yang telah digagas oleh Mahmoud Thaha yang merupakan guru dari Abdullah Ahmad An-Na im. Perlu dipahami bahwa gagasan ini dianggap sebagai salah satu jalan keluar umat Islam dari kebuntuan pemahaman syari ah selama ini.

Berangkat dari pemahaman terhadap istilah Makkiyah dan Madaniyyah Abdullah Ahmad An-Na im mengungkapkan :

$A$ close examination of the content of the Qur'an and Sunnah reveals two levels or stages of the message of Islam, one of the earlier Mecca priod and the other of the subsequent Medina stage. Futhermore, he maintened that the earlier message of Mecca is in fact the eternal

22 An-Na im. h. 60 
and fundamental message of Islam, emphasizing the inherent dignity of all human beings, regardless of gender, religious belief, race and so forth. That message was characterizedby equality between men and woman and complete freedom of choice in matters of religion and faith. Both of substance of the message of Islam and the manner of its propagation during the Mecca period were predicated on ismah, freedom of choice without any form or shade of compulsion or coercion. ${ }^{23}$

Tahap risalah Islam pada dasarnya memiliki dua tingkatan atau dua tahap risalah, pertama, periode awal Makkah dan kedua, tahap Madinah. Kemudian Abdullah Ahmad An$\mathrm{Na}$ im juga menegaskan melalui gagasan gurunya bahwa pesan abadi dan fundamental yang menjaga martabat seluruh umat manusia, tanpa adanya kesetaraan gender, keyakinan dalam beragama, ras dan lainnya dikandung dalam pesan-pesan ayat Makkah. pesan tersebut dapat diketahui dengan melihat indikasi dari pesan yang dikandung oleh ayat tersebut di mana ayat-ayat Makkah menjelaskan nilai-nilai persamaan antara laki-laki dan perempuan serta kebebasan penuh untuk memilih sikap dalam memeluk agama apa pun dan keimanan. Substansi pesan Islam maupun perilaku pengembangannya selama periode Makkah didasarkan pada `ismah, kebebasan tanpa adanya ancaman ataupun bayang-bayang kekerasan dan paksaan apapun.

Jika dilihat dari apa yang diungkapkan oleh Abdullah Ahmad An-Na im, sepertinya ia mengkategorikan pesan suatu ayat dengan kaitannya di mana tempat penurunannya dan substansi atau pesan ayat itulah yang menjadikan suatu ayat dapat dikategorikan Makkiyah atau Madaniyyah. Bukan seperti yang dijelaskan oleh ulama-ulama terdahulu yang merumuskan konsep Makkiyah dan Madaniyyah berdasarkan tempat di mana ayat itu diturunkan dan juga hanya untuk

${ }^{23}$ An-Na im. h. 52 menjelaskan ciri-ciri masing-masing dari ayat tersebut begitu juga dengan kaitannya satu sama lain..

Di sisi lain ia juga menjelaskan, istilah Makkiyah dan Madaniyyah hanya sekedar Istilah untuk mempermudah pengklasifikasian suatu pesan ayat. Padahal pengertian secara jelas mengenai Makkiyah dan Madaniyyah adalah dilihat langsung dari pesan ayat tersebut. Sehingga menurutnya jika ada ayat Makkiyah (dalam konsep ulama klasik) yang menekankan pada ekslusifitas komunitas beriman, maka dalam konsep Abdullah Ahmad An-Na im ayat ini dikategorikan ayat Madaniyyah. Begitu juga sebaliknya ketika ada ayat Madaniyyah (dalam pengertian ulama klasik) yang menekankan pada inklusifitas komunitas beriman maka dalam konsepnya ia dianggap sebagai ayat Makkiyah. ${ }^{24}$

Di sini ia menganggap bahwa ayatayat Makkah lebih dapat merangkul semua manusia tanpa adanya diskriminasi terhadap golongan tertentu. Yang nantinya apa yang diungkap oleh Abdullah Ahmad An-Na im di atas akan berimplikasi pada konsep nasakh yang ingin di evolusinya menjadi sebuah konsep yang dapat mempersatukan manusia tanpa adanya diskriminasi serta intimidasi terhadap satu golongan, agama, maupun ras.

Di sini Abdullah Ahmad An-Na im memahami bahwa pemahaman terhadap konsep Makkiyah dan Madaniyyah adalah untuk memahami ayat-ayat mana yang bersifat universal dan fundamental. Bahkan terkesan ayat-ayat Makkiyah memiliki kecendrungan bersifat universal dan memiliki pesan-pesan yang dapat merangkul semua umat manusia.

Sedangkan ulama-ulama dalam konsep ulama klasik cendrung memperluas cakupan dan manfaat kajian Makkiyah dan Madaniyyah ini, di mana para ulama melalui konsep Makkiyah dan Madaniyyah ini dapat

${ }^{24}$ Dahlan, Abdullah Abmad An-Na im Epistimologi Hukum Islam. h. 158 
mengetahui waktu, tempat serta situasi yang melatarbelakangi turunya suatu ayat dan surat Alquran. Melalui pemahaman terhadap konsep Makkiyah dan Madaniyyah akan memperoleh gambaran tentang situasi wahyu pada saat itu. ${ }^{25}$ Selain itu, konsep Makkiyah dan Madaniyyah digunakan untuk memahami kronologis nu₹ul, pengkategorian tematik, dan jenis sasaran (audiens) ayat-ayat Alquran. Dapat disimpulkan bahwa bahwa konsep Makkiyah dan Madaniyyah adalah salah satu alat analisis Alquran yang dapat memberikan gambaran tentang hubungan antara konteks historis dan konstruksi wacana Alquran.

Pada dasarnya pemahaman terhadap konsep Makkiyah dan Madaniyyah dapat memberikan gambaran penting mengenai dua fase dalam pembentukan teks Alquran, baik segi struktur, isi, dan konstruksinya. ${ }^{26} \mathrm{Di}$ sisi lain pemahaman terhadap konsep Makkiyah dan Madaniyyah menunjukkan adanya interaksi yang intensif dan harmonis antara teks dan realita sejarah. ${ }^{27}$ Kajian Makkiyah dan Madaniyyah dapat pula memberikan informasi tentang berbagai variasi gaya komunikasi Alquran untuk menyeru orang-orang yang beriman, kafir atau ahlu kitab, baik dari aspek linguistik dan stilistik atau aspek pesan dan wacana. ${ }^{28}$ Melalui pemahaman terhadap konsep Makkiyah dan Madaniyyah dapat dikaji karakteristik dan linguistik yang membedakan antara wacana Alquran dalam periode da`wah faktual historis.

Kemudian evolusi syari ah yan lebih dipahami kepada konsep nasakh dalam versi Abdullah Ahmad An-Na im, karena secara jelas ia pun mengungkapkan bahwa evolusi syari`ah yang dibangunnya adalah bentuk proses nasakh

25 Manna' Khalil Al-Qattan, Mabahits Fi Ulumil Qur an (Haramain: [ttp], [tth]). h. 53

${ }^{26}$ Andy Hadyianto, 'Makkiyah Madaniyyah Upaya Rekonstruksi Peristiwa Pewahyuan', Jurnal Studi AlQur'an Universitas Negeri Jakarta 7, no. 1 (2011): 75.

${ }^{27}$ Hadyianto.

${ }^{28}$ Subhi Sholeh, Mabahits fi 'Ulumil Qur an..., hal. 167 dan memiliki implikasi yang berbeda secara signifikan.

Sebagaimana yang telah diketahui selama ini bahwa para ahli hukum Islam terdahulu juga telah mengkaji mengenai nasakh ini secara lengkap, berangkat dari istilah nasakh secara etimologi yang memiliki empat makna. Izalah (menghilangkan), Tabdil (penggantian), Ta wil (Memalingkan), dan Naql (memindahkan dari satu tempat ke tempat lain). ${ }^{29}$ Kemudian ini menjadi dasar para ulama terdahulu untuk memberikan definisi nasakh yang lebih luas secara terminologi. Tidak hanya terbatas pada pembatalan atau penghapusan hukum semata, akan tetapi juga mencakup dalam kategori pengecualian, pengkhususan, dan pembatasan. Sedangkan ulama mutaakhirin mempersepit definisi nasakh dengan mendefinisikan nasakh sebagai sebuah bentuk pembatalan/penghapusan terhadap suatu hukum syara 'yang lebih dahulu diturunkan dan ditetapkan dengan hukum syara' yang datang belakangan. $^{30}$

Pada dasarnya Abdullah Ahmad An$\mathrm{Na}$ im tidak sepakat jika nasakh dimaknai dengan maksud penghapusan sesuai dengan pendapat para jumhur ulama. Menurut Abdullah Ahmad An-Na im bahwa pengahapusan beberapa ayat Alquran tersebut bukanlah secara final dan konklusif akan tetapi penghapusan tersebut semata-mata dipahami hanya sampai waktu pemberlakuan suatu hukum ayat Alquran tersebut tepat. ${ }^{31}$

Di samping itu dia juga menjelaskan:

When that superior level of the message was violently and irrationaly rejected and it was practically demonstrated that society at large was not yet ready for its implementation, the

29 Rosihan Anwar, Ulum Al-Qur an (Bandung: Pustaka Setia, 2010). h. 164

${ }^{30}$ Mahmud Muhammad al-Hanthur, Nasakh 'Inda Al-Fakhru Ar-Razi (Qahirah: Maktabah al-Adab, 2002). h. 43

31 An-Na`im, Toward an Islamic Reformation: Civil Liberties, Human Right, and International Law. h. 66 
more realistic message of the Medina stage was provided and implemented. In this way, aspects of the message of the Mecca period which were innappropriate for practical implementation within the historical context of the seventh century were suspended and replaced by the more practical principles revealed and implemented during the Medina stage. ${ }^{32}$

Abdullah Ahmad An-Na im menganggap bahwa ketika pesan Madinah diberlakukan bersamaan dengan itu pada dasarnya pesan Makkah ditolak. Hal ini dikarenakan pesan-pesan yang terdapat dalam ayat Makkah dianggap ketentuan yang terlalu maju untuk saat itu sehingga masyarakat Makkah belum siap untuk melaksanakan ketentuan-ketentuan dari pesan ayat-ayat Makkah. Sehingga dibutuhkanlah ayat-ayat yang lebih realistik dan lebih praktis untuk masyarakat periode itu dengan ketentuan ayatayat Madinah menggantikan ayat Makkah, karena ayat-ayat Madinah lah yang lebih cocok dan sesuai untuk masyarakat Islam pada abad ke-VII tersebut.

Dapat dipahami bahwa ada dua hal yang mendasar mengenai konsep nasakh (evolusi syari`ah) yang dibangun dan dikembangkan oleh Abdullah Ahmad AnNa im. Pertama, Nabi Muhammad dituntut untuk dapat dan harus mendawakwahkan serta mengajarkan seluruh bentuk ketentuan Allah yang terdapat dalam Alquran, dikarekan Alquran merupakan wahyu terakhir. Baik ajaran tersbut merupakan ketentuan yang harus diterapkan pada masa itu ataupun diterapkan untuk situasi yang tepat di ketika kondisi menuntutnya di masa depan. Kedua, umat manusia diperintahkan oleh Allah untuk belajar melalui pengalaman yang praktis, hal ini dikehendaki Allah demi martabat dan kebebasan yang dilimpahkan Allah untuk seluruh umat manusia. Karena pesan Makkah tidak bisa diterapkan, maka Pesan Makkah tersebut ditunda dan digantikan oleh ayat-ayat
Madinah yang lebih praktis. Cara yang demikian memungkinan untuk masyarakat akan memiliki keyakinan bahwa ayat-ayat Makkah dapat diterapkan kembali untuk memenuhi kebutuhan masyarakat modern saat ini. ${ }^{33}$

Hal yang menarik dari konsep nasakh (evolusi syari ah) yang diusung oleh Abdullah Ahmad An-Na`im adalah dia menggunakan konsep Makkiyah dan Madaniyyah untuk menentukan konsep nasakh (evolusi syari ah). Menurutnya syari ah yang selama ini dikenal kebanyakan bersandar kepada ayat ayat Madaniyyah. Ia memberikan katogori bahwa pada dasarnya ayat-ayat Makkiyah lah yang mengandung pesan universal dan fundamental. Sedangkan ayat-ayat Madaniyyah banyak mengandung pesan-pesan yang bersifat partikular bahkan mengandung pesan yang bersifat diskriminasi dan bertentangan dengan Hak Asasi Manusia. Maka ia menyimpulkan bahwa untuk menjawab persoalan-persoalan kontemprer saat ini ayat-ayat Makkiyah lah yang cocok untuk diterapkan.

Sehingga jika ayat-ayat Makkah yang telah di-nasakh dianggap dapat diberlakukan untuk umat Islam karena sesuai untuk situasi pada saat ini, maka tidak ada salahnya jika ayat Makkah tersebut diberlakukan kembali. Dan menggantikan ayat Madinah, akan tetapi tidak menghapuskan secara final hanya menunggu ketika ayat Makkah tersebut tidak relevan lagi dan ayat Madinah lah yang dibutuhkan. Sehingga dapat dikatakan bahwa nasakh yang diusung Abdullah Ahmad An-Na im adalah metode nasakh terbalik dengan menggunakan konsep Makkiyh dan Madaniyah.

Konsep nasakh (evolusi syari ah) yang diusung oleh Abdullah Ahmad An-Na im sebenarnya berkaitan dengan pemahamannya terhadap surat Al-Baqarah ayat 106: 


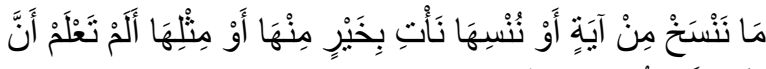

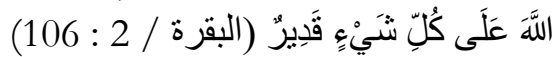

Artinya : Ayat mana saja yang kami nasakh-kan, atau kami jadikan manusia lupa kepadanya, kami datangkan yang lebih baik dari padanya atau sebanding dengannya. Tidakkah kamu mengetabui bahwa sesunggubnya Allab Maba Kuasa atas segala sesuatu?. (Q.S Al-Baqarah/2: 106)

Nasakh (evolusi syari ah) seperti yang dijelaskan oleh Abdullah Ahmad An-Na im di atas secara sederhana merupakan perpindahan dari suatu ayat Alquran kepada ayat yang lain. Dari suatu ayat yang diturunkan di Makkah yang berfungsi untuk mengatur masyarakat pada abad ke-VII yang pada waktu itu terlalu maju dan oleh karena itu dibatalkan dengan ayat-ayat madinah yang dianggap dapat diterima dan dianggap pas untuk masyarakat pada saat itu.

Kata نُنْبِهَ pada ayat yang berbicara mengenai nasakh di atas dipahami oleh Abdullah Ahmad An-Na`im dengan makna menunda bukan dengan mengganti/menghapus. Dengan demikian Abdullah Ahmad An-Na im memahami bahwa ayat di atas berbicara mengenai penundaan pelaksanaan atau penerapan suatu ayat.

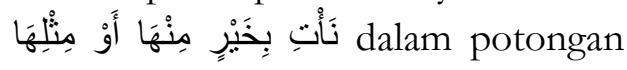
ayat ini Abdullah Ahmad An-Na im memahami "Kami datangkan ayat yang lebih baik" sehingga kalimat ini bermakna mendatangkan ayat yang lebih dekat dengan pemahaman manusia dan lebih sesuai dengan kondisi mereka ketimbang ayat yang telah ditunda. Kemudian kata "atau ayat yang sebanding dengannya" sehingga maksud ayat ini dapat dipahami mengembalikan suatu ayat yang sama dikarenakan ayat tersebut memungkinkan dan relevan untuk diterapkan kembali. Seolah-olah penghapusan ayat itu sesuai dengan kebutuhan situasi, dan ditunda hingga waktunya tepat. ${ }^{34}$

Karena pemahaman Abdullah Ahmad An-Na`im terhadap ayat inilah berimplikasi terhadap pemahamannya kepada konsep nasakh yang diusungnya. Bahkan sejauh ini pemahaman Abdullah Ahmad An-Na im dengan konsep nasakh-nya di anggap sebagai solusi untuk menjadikan hukum dalam Alquran lebih universal dan dapat merangkul seluruh umat manusia, dengan memilah ayat-ayat yang sesuai dengan memiliki nilai-nilai keadilan untuk seluruh umat manusia. Dan perlu dicatat bahwa nasakh Abdullah Ahmad An-Na im melihat kepada fase Makkah dan Madinah.

Di sini terlihat bahwa Abdullah Ahmad An-Na im mengusung konsep nasakh dengan tidak menggunakan syarat yang jelas karena pemberlakuan nasakh menurut Abdullah Ahmad An-Na im adalah nasakh yang bersifat tentatif sesuai dengan kondisi dan kebutuhan masyarakat dan hanya dilandasi dengan pemahaman terhadap surat Al-Baqarah ayat 106. Serta mempertimbangkan ayat-ayat yang tidak bertentangan dengan gender, deskriminatif dan hak asasi manusia maka ayat tersebut dianggap ayat Makkiyah.

Sedangkan ulama terdahulu secara sistematis telah menetapkan syarat dapat diberlakukannya nasakh. Salah satunya Abu Zahrah yang menjelaskan bahwa ada empat syarat untuk dapat diberlakukannya nasakh dalam nash. Pertama, hukum yang di-mansukb tidak diikuti oleh ungkapan yang menunjukkan atas keabadian hukum yang terkandung di dalamnya. Kedua, hukum yang mansukh tersebut bukan termasuk ke dalam kategori masalah yang telah disepakati ulama terhadap kebaikan dan keburukannya. Ketiga, nash yang me-nasikh harus turun lebih akhir dari nash yang dimansukh. Keempat, nasakh hanya dapat

34 An-Na im, Toward an Islamic Reformation: Civil Liberties, Human Right, and International Law. h. 59-60 
diberlakukan jika kedua nash tersebut sudah tidak dapat dikompromikan. ${ }^{35}$

Dalam kitab Nawasikh Alquran, Ibnu Jauzi menjelaskan bahwa ada beberapa syarat terjadinya nasakh. Pertama, kedua hukum dari nash (antara nasikh dan mansukh) memang terlihat jelas saling bertentangan dan memang tidak dapat dikompromikan ataupun ditariih. Kedua, hukum yang di-nasakh telah berlaku sebelumnya, baik dari segi pembicaraan maupun sejarah. Ketiga, hukum yang di-nasakh disyariatkan dengan berlandaskan Alquran. Keempat, ayat dan hukum yang me-nasikh merupakan suatu yang disyariatkan artinya jika ada hukum yang tidak disyariatkan secara nash tidak termasuk dalam kategori nash. Kelima, cara penetapan hukum yang di-nasakh harus sama dengan cara penetapan hukum yang menasak. ${ }^{36}$

Adapun pengaplikasian atas metode pembaruan yang menjadi tolok-ukur Abdullah Ahmad An-Na im dalam mengkaji setiap permasalahan hukum dapat diklasifikasikan kepada 3 (tiga) kategori. Sebagaimana berikut: ${ }^{37}$

\section{$\underline{\text { Teks }}$}

Teks dalam hal ini merupakan istilah lain dari nash (al-Qur'an dan al-Hadits,). Dalam hal sumber, ulama-ulama tradisonal dalam memahami tentang qath $i$ dilalah dan zhanni dilalah. Ulama tradisonal mengatakan bahwa qath $i$ dilalah adalah teks tidak memiliki arti lebih dari satu, atau teks yang tidak bisa ditafsirkan/artinya pembaca langsung sampai pada apa yang dimaksud teks. Seperti pada surat Al-Baqarah ayat 228:

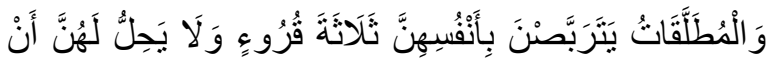

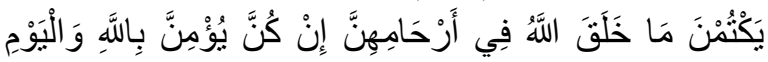

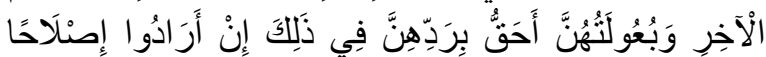

35 Muhammad Abu Zahrah, Ubsul Fiqh, Terj. Saifullah Maksum (Jakarta: Pustaka Firdaus, 2008). h. 293294

${ }^{36}$ Ibn al Jauzi, Nawasikh Al-Qur'an (Madinah: Ihya al-Turats al-Islami, 1984). h. 97

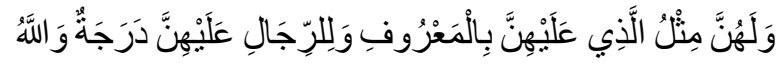

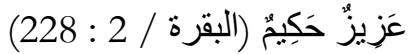

Artinya :

Wanita-wanita yang ditalak bendaklah menahan diri (menunggu) tiga kali qutru. Tidak boleh mereka menyembunyikan apa yang diciptakan Allah dalam rahimnya, jika mereka beriman kepada Allah dan hari akbirat. Dan suami-suaminya berbak merujukinya di masa-masa menanti itu, jika mereka (para suami) menghendaki islah, Dan para wanita mempunyai bake yang seimbang dengan kewajibannya menurut cara yang makruf. Akan tetapi memiliki satu tingkat kelebiban daripada istrinya. (Q.S AlBaqarah/2: 228)

Kata ${ }^{2}$ merupakan contoh kata yang qath $i$ dalalah karena pembaca dapat langsung memahami arti dari kata ثَنَانَ adalah tiga tanpa ada penafsiran yang lain atau membutuhkan penafsiran.

Sedangkan zhanni dalalah adalah teks yang memiliki arti lebih dari satu, atau teks yang bisa ditafsirkan/atau pembaca perlu menafsirkan teks untuk sampai ke maksud ayat dan ini sebagai sumber sekunder. ${ }^{38}$ Seperti kata قُرُوِ yang perlu adanya penafsiran untuk sampai ke pada maksud kata tersebut. Sehngga ada ulama yang menafsirkan kata قُرُوڤ berarti suci dan ada juga ulama yang menafsirkan kata قُرْوْ dengan arti haid.

Sedangkan Abdullah Ahmad AnNa im berbeda dalam memahami konsep qath $i$ dalalah dan zhanni dalalah. Menurut Abdullah Ahmad An-Na'im, teks yang qath'i dilalah adalah teks yang bersifat universal ('amm) atau yang mengandung nilai-nilai kemanusiaan, sedangkan teks yang dranni dilalah yang memiliki arti jelas dan rinci atau teks yang mengancam nilai-nilai kemanusiaan (keadilan). ${ }^{39}$

\footnotetext{
${ }^{37}$ Dahlan, Abdullah Abmad An-Na im Epistimologi Hukum Islam. h. 135

${ }^{38}$ Dahlan.

${ }^{39}$ Dahlan. h. 104
} 
Dalam konteks 'amm dan khashsh, pendapat yang dipegangi Abdullah Ahmad An$\mathrm{Na}$ im lebih mendekati takhshish munfashil, yakni men-takhshish yang khas dengan yang 'amm, seperti ayat tentang waris di takhsis dengan ayat tentang keadilan. Dalam hal ini Abdullah Ahmad An-Na im memformulasikan teori ijtihad-nya dengan menggunakan prinsip dasar 'amm.

Dengan demikian, dalam hal ijtihad Abdullah Ahmad An-Na im terlebih dahulu membongkar pemahaman klasik tentang konsep qath $i$ diilalah dan dranni dilalah, serta 'amm dan khas. Jika demikian berarti Abdullah Ahmad An-Na'im menginginkan diadakan suatu dekonstruksi konsep ushul fikih yang telah dibangun oleh ulama perintis. ${ }^{40}$

Perlu dijelaskan juga bahwa metode tersebut menafikan anggapan-anggapan lama tentang kesakralan nash-nash yang bersifat qath'i dilalah dan mengkhususkan nash-nash yang bersifat dzanni dilalab saja yang menjadi ladang ijtihadi. Alasan mendasar Abdullah Ahmad An$\mathrm{Na}$ im atas gagasa $\mathrm{n}$ tersebut adalah bahwa keberadaan syari'at berdasarkan realitas historis merupakan suatu wujud apresiasi terhadap adanya perbaikan sosio-politik pada masa itu. Apa yang dilakukan syari'at adalah melakukan perbaikan sebisa mungkin untuk mengurangi dampak negatif diskriminasi. ${ }^{41}$

\section{Nilai-nilai kemanusiaan}

Nilai-nilai kemanusiaan dimaksudkan bahwa keadilan dengan tanpa diskriminasi baik terhadap wanita maupun non-Muslim merupakan sesuatu yang urgen untuk menjadi pertimbangan di dalam mengkaji setiap persoalan hukum yang muncul, seperti kesamaan dan kebebasan. Dalam hal ini AnNa'im meyakini bahwa dengan mempertimbangkan nilai-nilai kemanusiaan di dalam mengkaji nash hukum maka akan dapat melepaskan diri dari beban-beban lama yang membebani umat Islam dewasa ini.

Kesemuanya itu menurut Abdullah Ahmad An-Na im hanya dapat terwujud dengan beberapa penopang, yakni sebagaimana berikut:

1. Kebebasan nurani; Yakni, adanya kebebasan untuk melakukan segala tindakan yang dapat dipertanggung jawabkannya, serta tidak melanggar hak-hak manusia lainnya.

2. Melakukan tindakan berdasarkan kemauan diri sendiri; Yakni, seseorang dikatakan bebas apabila ia dalam melakukan setiap aktifitasnya berdasarkan kemauannya sendiri tanpa ada paksaan dari pihak lain, baik secara langsung maupun tidak langsung.

3. Menjamin keselamatan akal manusia; yakni, hukum Islam harus memperhatikan keselamatan akal manusia sebagai dasar pijakan dalam setiap melakukan aktifitas yang bebas dan bertanggung jawab.

4. Pemberdayaan terhadap manusia; Yakni, hukum Islam harus memberdayakan manusia baik dalam tataran intelektual maupun dalam tataran perilaku. ${ }^{42}$

\section{Akal (logika)}

Dalam hal ini merupakan konsekuensi yang dihasilkan atas adanya kedua pertimbangan diatas, yakni teks dan nilai-nilai kemanusiaan. Abdullah Ahmad An-Na im mengatakan bahwa akal merupakan perantara dalam menghubungkan teks dengan realitas kemanusiaan. Oleh karenanya Abdullah Ahmad An-Na im di dalam upaya memahami nash menempatkan posisi akal (ijtihad,) menduduki posisi ke tiga dengan prinsip menghasilkan produk hukum Islam yang lebih manusiawi. Dalam hal ini pula, Abdullah Ahmad An-Na im mengimani bahwa ketika akal digunakan untuk mengkaji suatu sumber hukum nash dengan terlepas dari pola pikir madzhab-madzhab yang

${ }^{40}$ Dahlan. h. 108

${ }^{41}$ Mujaid Kumkelo, dkk, Figh HAM..., hal. 135

${ }^{42}$ Dahlan, Abdullah Abmad An-Na'im Epistimologi Hukum Islam. h. 137 
telah masyhur akan menghasilkan produk hukum yang lebih manusiawi, dengan cara melakukan selalu mengupayakan untuk mengkombinasikan antara teks hukum Islam dengan nilai-nilai kemanusiaan (berdasarkan standar HAM internasional). ${ }^{43}$

Kendatipun demikian radikal pemikiran Abdullah Ahmad An-Na im di dalam setiap mengkaji hukum Islam dari sumbernya, ia tetap mengakui bahwa al-Qur'an dan hadis merupakan sumber primer hukum Islam yang tidak dapat dipisahkan di dalam setiap usaha seseorang dalam mengkaji hukum Islam dewasa ini. Hanya saja yang membedakan Abdullah Ahmad An-Na`im dengan pemikir hukum Islam lainnya, terutama dari kalangan intelektual muslim tradisional, Abdullah Ahmad An-Na`im lebih mengkedepankan nilai-nilai kemanusian (keadilan) di dalam setiap menginterpretasi nash. Sebagaimana yang telah penulis singgung diatas, bahwa Abdullah Ahmad An-Na im benar-benar menyusun ulang teori ushul fikih yang telah dibangun oleh ulama klasik (masa imam madzhab). Dalam hal ini ia mempercayai bahwa al-Syafi'i merupakan peletak dasar teori-teori yang ada di dalam ushul fiqh. $^{44}$

Jika dibagankan setidak konsep metode evolusi syari ah Abdullah Ahmad An$\mathrm{N}$ a im sebagai berikut:

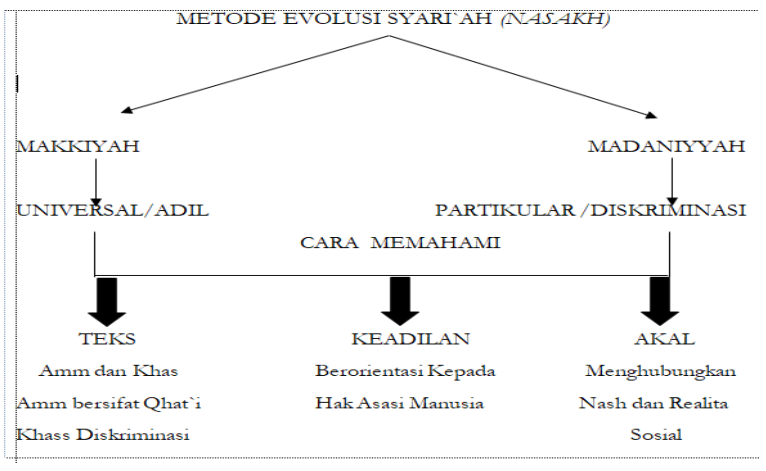

Sedangkan jika ditabelkan terlihat perbedaan signifikan antara kriteria evolusi syariah Abdullah Ahmad An-Na`im dan

${ }^{43}$ Dahlan. h. 136 nasakh yang dipahami dalam tradisi klasik serta pemahaman terhadap qath $i$ dan zhanni aldalalab:

\begin{tabular}{|l|l|l|l|}
\hline No. & Kriteria & Tradisional & $\begin{array}{l}\text { Abdullah } \\
\text { Ahmad An- } \\
\text { Na im }\end{array}$ \\
\hline 1 & Nasikh & Madaniyah & Makkiyah \\
\hline 2 & Mansukh & Makkiyah & Madaniyyah \\
\hline 3 & $\begin{array}{l}\text { Qath } i \\
\text { dalalah }\end{array}$ & $\begin{array}{l}\text { Ayat-ayat } \\
\text { yang } \\
\text { rinci/jelas }\end{array}$ & $\begin{array}{l}\text { Ayat-ayat yang } \\
\text { bersifat } \\
\text { universal (amm) }\end{array}$ \\
\hline 4 & $\begin{array}{l}\text { Zhanni } \\
\text { dalalah }\end{array}$ & $\begin{array}{l}\text { Ayat-ayat } \\
\text { Universal } \\
\text { (amm) }\end{array}$ & $\begin{array}{l}\text { Ayat-ayat yang } \\
\text { rinci dan jelas }\end{array}$ \\
\hline
\end{tabular}

Jika dilihat dan dipahami dalam kasus ini Abdullah Ahmad An-Na im memposisikan dirinya sebagai seorang mujtabid mutlak. Hal ini terlihat dari metode istinbath hukum yang diajukannya, yakni dengan metode dekonstruksi syari'ah. Ia bukan lagi sekedar orang yang mengkaji hukum Islam berdasarkan hasil yurisprudensi hukum masa abad pertengahan Masehi (masa para Imam madzhab), melainkan ia menginginkan agar pengkajian hukum Islam dilakukan secara fundamental (mendasar), bahkan sampai kepada hal radikal.

Syari'at menurut Abdullah Ahmad An-Na`im bukanlah sesuatu yang sakral, sebagaimana anggapa kebanyakan orang. Oleh karenanya siapapun bisa mengkaji syari'at berdasarkan sumber asalnya (al-Qur'an dan hadis) tanpa dipengaruhi oleh tawaran hukum yang sudah ada dan/atau model pemikiran yang dibangun ulama abad pertengahan untuk kemudian direalisasikan berdasarkan pemahamannya terhadap nash syari'at. Dalam hal ini ia mengklaim bahwa syari'at bukanlah keseluruhan dari Islam itu sendiri, melainkan ia hanya sebuah hasil interpretasi terhadap nash (selaku sumber hukum asal,) yang dipahami berdasarkan konsep historis tertentu.

Berdasarkan asumsi-asumsi demikian, dalam hal metodologi istinbath hukum Abdullah Ahmad An-Na im menolak tawaran formulasiformulasi metode ijtihad yang dicetuskan oleh

${ }^{44}$ Dahlan. 
ulama abad pertengahan (masa kejayaan hukum Islam atas dasar eksistensi para Imam Madzhab,). Meskipun demikian halnya terhadap usaha-usaha kaum modernis (pembaharu Islam) di dalam melakukan modernisasi Islam, an-Nai'im menolaknya atas dasar pertimbangan mereka yang tetap terpaku kepada formulasi-formulasi yang ditawarkan oleh ulama abad pertengahan.

\section{ANCAMAN DAN TANTANGAN TEORI EVOLUSI SYARIAH (NASAKH) ABDULLAH AHMAD AN-NA'IM SEBAGAI METODE ISTINBATH HUKUM KONTEMPORER}

Berangkat dari wacana transformatif yang disajikan oleh Abdullah Ahmad An-Na im di mana transformatif dipahami sebagai sebuah tanggung jawab bagi mereka yang termaginalkan, melakukan perubahan demi mencapai kebebasan dan keadilan sosial selain kehidupan ritual. Abuddin Nata menjelaskan bahwa pemikiran transformatif adalah mengubah dalam arti memberikan perubahan kepada kondisi masyarakat yang termaginalkan oleh modernisasi dan pembangunan, serta menjadikan masyarakat berdasarkan cita-cita Islam. $^{45}$

Pada dasarnya Islam transformatif memiliki karakteristik yang selalu mengupayakan dan bertujuan untuk meralisasikan cita-cita Islam yaitu membawa dan memberi rahmat kepada seluruh umat manusia. Kemudian menunjukkan bahwa adanya keseimbangan antara ajaran Islam yang bersifat ritual dengan misi Islam. Dan juga menegaskan nilai-nilai kemanusiaan dan demokratis. Fokus kepada kehidupan sosial masyarakat yang aktual. ${ }^{46}$

Rahardjo menjelaskan bahwa ada bentuk tiga golongan cendikiawan muslim berbeda ketika memahami makna transformasi. Kemudian Rahardjo juga menjelaskan bahwa pada dasarnya ketiga golongan ini memiliki kecendrungan masing-masing dan memiliki perbedaan yang signifikan. Pertama, mereka memahami makna transformasi secara sederhana dengan melakukan transformasi dari masyarakat agraris menjadi masyarakat industri. Kedua, mereka memaknai transformasi sebagai doktrin atau ajaran atau etika yang harus diaktualisasikan ke dalam aspek kehidupan, seperti ekonomi Islam. Ketiga, transformasi diartikan sebagai gerakan revolusioner atau radikal. ${ }^{47}$

Pada dasarnya konsep pemikiran Abdullah Ahmad An-Na`im yang telah disajikan pada penjelasan sebelumnya sangat patut diapresiasi karena ia sangat produktif terlebih pada pemikirannya dalam menghadapkan syari at dan HAM. Bahkan di satu sisi pemikiran yang disajikan Abdullah Ahmad An-Na im setidaknya dapat membatah tuduhan non-muslim yang beranggapan selama ini hukum Islam bertolak belakang dengan hukum-hukum International dan Hak Asasi Manusia. Terutama ketika Islam dianggap sebagai sebuah agama teroris dalam stigma negatif negara-negara Eropa. Akan tetapi ancam dan tantangan ketika pemikiran Abdullah Ahmad An-Na im disajikan sebagai sebuah metode istinbath kontemporer tentu tidak dapat terelakkan.

Karena keberanian Abdullah Ahmad An-Na im yang telah mendekonstruksi metode ulama klasik yang telah mapan sebagai sebuah metode istinbath. Menyebabkan Mohammed Arkoun secara jelas menyampaikan ketidak setujuannya dengan pendekatan yang dipakai oleh Abdullah Ahmad An-Na im. Sebagaimana ia menyatakan:
45 Abuddin Nata, Peta Keragaman Pemikiran Islam Di Indonesia (Jakarta: PT Raja Grafindo, 2001). h. 78 ${ }^{46}$ Nata.
47 Dawam Raharjo, Intelektual Intelegensia Dan Perilaku Politik Bangsa: Risalah Cendikiawan Muslim (Bandung: Mizan, 2008). h. 106 
Saya (Mohammed Arkoun) tidak setuju dan tidak mendukung metodologi dan epistimologi yang dipilih oleh Abdullah Abmad AnNa im untuk membangun sebuah reformasi Islam, yang dia inginkan menjadi sesuatu yang modern akan tetapi sekaligus selaras dengan ortodoksi. ${ }^{48}$

Arkoun mengungkapkan bahwa isuisu yang jawaban-jawabannya dicoba ajukan oleh Abdullah Ahmad An-Na`im dalam kerangka metodologi pembaruan ortodoks (yang disebutnya metodologi yang memadai) adalah bagian yang tak terpisahkan dari proses revolusioner yang telah berlangsung untuk pertama kalinya di Eropa dan hanya di Eropa konstitualisme modern, hukum International modern, hak asasi manusia, dan hukum pidana.

Selanjutnya Arkoun juga mengkritik bahwa postur pemikiran reformasi yang dijelaskan oleh Abdullah Ahmad An-Na im memiliki aspek yang sangat lemah dan tidak dapat diterima. Arkoun memngungkapkan bahwa sikapnya dalam menggasas metodologi yang memadai tidak mempertimbangkan isu wahyu sebagai suatu yang berlaku umum bagi umat Islam, Kristen maupun Yahudi. Menurut Arkoun sebelum kita berusaha unruk melahirkan penafsiran yang modern terhadap Alquran, seharusnya mempertimbangkan wahyu sebagai sebuah gejala kultural, historis, simiotik dan antropologis dalam berbagai manifestasi historis dan faktualnya. ${ }^{49}$ Inilah yang tidak dilakukan Abdullah Ahmad An$\mathrm{Na}$ im ketika melakukan sebuah reformasi metodologi yang dianggapnya sebagai sebuah metode yang memadai.

Menurut Arkoun bahwa untuk mengklaim otoritas Alquran dalam semua bidang yang berhubungan dengan modernitas, tidak cukup dengan mengolah ayat-ayat
Alquran, atau membangun hirarki nilai-nilai baru untuk semua ayat Alquran dan hadits, atau memproyeksikan unsur-unsur hukum modern kepada teks Alquran dan hadis dengan memisahkannya dengan konteks historisnya. ${ }^{50}$ Inilah yang Abdullah Ahmad An-Na im lakukan terhadap metodologi yang dibangunnya dengan menghilangkan historitas dari Alquran tersebut.

Ishtiaq Ahmed juga mengkritisi dengan menuntut apakah Abdullah Ahmad An$\mathrm{Na}$ im bisa mengurutkan ayat-ayat Makkah dan dengan menerapkan metodologinya, mengemukakan hukum yang dapat ditarik dari penerapan metodologi tersebut. Karena hal ini tentu sangat diperlukan untuk memperlihatkan bagaimana interpretasi semacam yang digagas oleh Abdullah Ahmad An-Na im agar dapat sangat dimengerti. Kemudian ia juga mengungkapkan apa dasar untuk mempercayai bahwa semua ayat yang diwahyukan di Makkah secara konsisten mendukung universalisme, kebebabasan berkeyakinan dan beragama bahkan kesetaraan. Menurutnya dari sudut pandang religius tidak bisa bersikap netral antara keyakinan kepada Allah dan ketidak berimanan. Secara tegas orang beriman adalah orang baik dan orang kafir dikutuk. Bahkan ia mencurigai bahwa walaupun Alquran Makkah memang menekankan nilai-nilai universalisme, toleransi, dan koeksistensi damai yang secara garis besar dinilai positif, akan tetapi ia tidak mengakui kebenaran praktek dan kepercayaan penduduk Makkah yang percaya kepada sejumlah dewa dan menyembah berhala. Bahkan terhadap kepercayaan seperti itu Alquran tidak mengurangi kutukannya, bahkan di Makkah. Misalnya seperti dalam surat alBayyinah ayat $6:^{51}$
48 Abdullah Ahmad An-Na im, Mohammed Arkoun, and dkk., Islamic Law Reform And Human Rights Challenges And Rejoinders, Terj. Dekonstruksi Syari ah (II), Diterjemahkan Farid Wajidi (Yogyakarta: LKiS, 1996). h.

\footnotetext{
49 An-Na im, Mohammed Arkoun, and dkk. h. 21

50 An-Na im, Mohammed Arkoun, and dkk.

51 An-Na im, Mohammed Arkoun, and dkk. h. 76-
} 11 


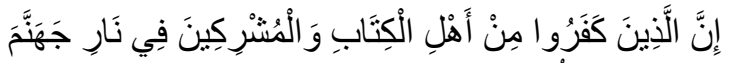

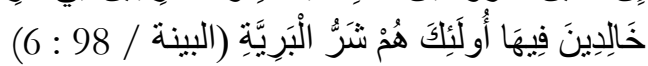
Artinya:

Orang-orangyang tidak beriman di antara ablu al-kitab dan kaum penyembah berbala akan dibakar selamanya dineraka. Mereka adalah seburuk-buruk makbluk. (Q.S AlBayyinah/98: 6)

Bahkan masih ada ayat-ayat lain yang tidak menyerukan tolerasnsi kepada kepercayaan yang palsu. Seandainya bukan demi penentangan tanpa kompromi terhadap politeisme dan ritual para kekerabatnya di Makkah, Muhammad tidak akan menempuh jalan yang membawanya kepada ketegangan yang semakin panas dan konfrontasi antara beliau dengan para kepala suku di Makkah, yang berpuncak pada peristiwa Hijrah ke Madinah pada tahun $622 \mathrm{M}$.

Kemudian ia juga menjelaskan bahwa apakah memang ada pernyataan otentik dari Nabi yang mengemukakan bahwa dia sadar memberikan pesan tersendiri kepada para pengikutnya dalam dua porsi Alquran yang berbeda. Jika Abdullah Ahmad An-Na`im mengkalim bahwa pesan-pesan Madinah merupakan pesan yang partikular dan banyaknya dekriminasi atau hal-hal negatif lainnya, di sini Ishtiaq Ahmed mengajak untuk kembali memutar ulang bagaimana Islam di Madinah. ${ }^{52}$ Secara tidak langsung Ishtiaq Ahmed mengungkapkan bagaimana bisa kita mengkalim bahwa banyaknya ayat-ayat Madinah serta budaya sosial masyarakat Madinah banyak menekankan kepada sikap yang diskriminasi dan bersifat partikular, jika banyak fakta-fakta sejarah yang mengungkapkan kejayaan Islam dengan menerapkan sistem-sistem serta syari ah yang diberlakukan di Madinah tersebut.

Bahkan Ishtiaq Ahmed menganggap tidak ada yang dapat dicapai dengan menempatkan konstitualisme dan Hak Asasi Manusia sebagai tumpuan tertinggi dalam sebuah metodologi. Menurutnya hal ini hanya dipengaruhi oleh kelompok humanisme dan toleransi universalisme. Sedangkan ayat-ayat Alquran pada dasarnya telah menjaga hal-hal yang demikian.

Di sini sangat terlihat jelas bagaimana Ishtiaq Ahmed mengkritik konsep Makkiyah dan Madaniyah yang dijelaskan oleh Abdullah Ahmad An-Na im. Jika ditarik kesimpulan kritikan yang disampaikan oleh Ishtiaq Ahmed ini lebih kepada pembuktian dimana tidak semua ayat-ayat Makkah yang bersifat universal dan tidak semua ayat-ayat Madinah yang bersifat partikular dan deskriminasi. Dengan kata lain secara tidak langsung melalui penjelasannya tersebut Ishtiaq Ahmed menolak konsep Makkiyah dan Madaniyyah yang dibangun oleh Abdullah Ahmad An-Na im untuk menjadikannya sebuah acuan dalam melakukan metode/ijtihad yang memadai dan modern.

Moh. Dahlan juga mengkritisi metode yang di sajikan oleh Abdullah Ahmad AnNa im ini. Dahlan menjelaskan bahwa ada beberapa kelemahan yang terdapat dalam metode evolusi syari ah Abdullah Ahmad An$\mathrm{Na}$ im. Ia menjabarkan kelemahan tersebut dalam bukunya yang berjudul "Abdullah Ahmad An-Na im dan Espistimologi Hukum Islam”.

Ia menjelaskan bahwa metode yang disajikan oleh Abdullah Ahmad An-Na im hanya mengandalkan teks kebahasaan saja, sehingga ia tidak bisa menghindar ataupun mencari solusi Islam ketika tidak ada keterangan eksplisit dalam Alquran atau sunnah. Padahal, pembacaan hukum Islam yang hanya mengandalkan teks akan menciptakan suatu sikap yang apologis. Sehingga sikap apologis ini pada akhirnya akan memunculkan sikap ambiguitas di antara mengikuti HAM atau nilai-nilai keislaman. Hal ini disebabkan karena

${ }^{52}$ An-Na im, Mohammed Arkoun, and dkk. h. 78 
tidak mengikutkan pesan teks yang utama yang memiliki fungsi normatif terhadap seluruh pesan teks yang partikular. Kedua kritikan di atas mengakibatkan metode yang disajikan oleh Abdullah Ahmad An-Na im menjadi tidak utuh dalam memahami teks hukum Islam. Padahal, pemahaman ini dapat memunculkan konflik internal di masing-masing kelompok Islam dengan mengklaim hanya hasil dari pemahamannya terhadap pesan-pesan nash yang paling benar dikarenakan sudah mendasar dari teks Alquran dan sunnah. Di samping itu pemikiran Abdullah Ahmad An-Na im yang hanya berpusat pada teks akan sangat mudah dipatahkan oleh pemikiran lain yang juga berpusat pada teks. ${ }^{53}$

Meskipun Abdullah Ahmad An$\mathrm{Na}$ im menkritik konsep ijtihad ulama klasik akan tetapi ia masih terperangkap dalam ruang objektifisme dalam menjawab realitas konkret seperti yang pernah di alami oleh Imam alSyafi $i$, atau mungkin hanya sekedar melengkapi paradigma lama saja agar tidak terlalu dogmatik. Selain itu pemikiran Abdullah Ahmad An$\mathrm{Na}$ im masih bersifat tekstual-reproduktif atau menurut Moh Dahlan masih bersifat Bettian; cara penyelesaian yang selalu berbicara justifikasi dan legitimasi atau hanya sekedar mengeluarkan hukum yang berarti bercorak dogmatik atau logic of repeatation, bukan produktif atau post-dogmatic. Menurut Moh Dahlan hal tersebut muncul karena pemikiran Abdullah Ahmad An-Na`im terlalu mengandalkan pemikiran Thah yang masih teks-oriented, yaitu hanya sekedar pindah dari satu teks ke teks yang lain, atau dapat dikatakan ia tidak bisa memberi ruang yang luas terhadap akal, dalam arti sulit untuk memahami teks wahyu dalam menjawab isu-isu kekinian. ${ }^{54}$

Di sini terlihat bahwa Moh. Dahlan secara tegas mengkritik pemikiran Abdullah

${ }^{53}$ Dahlan, Abdullah Abmad An-Na im Epistimologi Hukum Islam. h. 295

${ }^{54}$ Dahlan. h. 297-298
Ahmad An-Na im dari aspek epistimologinya. Di mana ia menjelaskan kelemahan dari sisi aplikatif pemikiran Abdullah Ahmad An-Na im sebagai sebuah bentuk epistimologi hukum Islam.

Busyro dalam tulisannya yang bejudul Abdullah Ahmad An-Naïm dan Pemikiran Liberalisnya menjelaskan pada dasarnya dalam pemikiran yang digagas oleh Abdullah Ahmad An-Na`im tidak ditemui sesuatu yang baru, karena sebenarnya ia hanya ingin menolak bentuk intervensi negara terhadap penerapan syariah. Dikarekan hal tersebut bertentangan dengan sifat dan tujuan syari ah itu sendiri yang hanya bisa dijalankan secara sukarela bagi pemeluknya. Karena menurutnya jika syari ah diterapan melalui syari $a h$, maka syari ah akan kehilangan otoritasnya serta nilai keagamaannya. Di samping itu menurut Busyro bahwa ide yang disajikan Abdullah Ahmad An$\mathrm{Na}$ 'im sangat bersifat absurd, hal ini disebabkan karena selama ini perangkat hukum dalam syari ah meniscayakan campur tangan megara untuk mencegah terjadinya kekacauan dan konflik sosial. Rasanya sangt sulit membayangkan jika negara untuk tetap netral. Selanjutnya pemahaman Abdullah Ahmad AnNa im yang menjelaskan bahwa setiap orang memiliki kemampuan mengakses, memahamai dan berinteraksi dengan Alquran dan Sunnah. Agaknya apa yang disampaikan oleh Abdullah Ahmad An-Na im menurut Busyro merupakan pemahaman yang sangat berbahaya karena akan menghasilkan asumsi bahwa agama merupakan hasil kreasi manusia, dengan arti lain Islam merupakan produk rekayasa pikiran manusia. ${ }^{55}$

Di sisi lain Busyro juga menjelaskan bahwa Abdullah Ahmad An-Na im tidak konsisten karena di satu sisi ia menginginkan demokrasi dan di sisi lain ia bersifat otoriter. Karena Abdullah Ahmad An-Na im yang

55 Busyro, 'Abdullah Ahmad An-Na`im Dan Pemikiran Liberalisnya', ALHURRIY AH: Jurnal Hukum Islam (ALHURRIYAH JOURNAL OF ISLAMIC $L A W)$ 15, no. 2 (2014): 55. 
menawarkan kemungkinan penerapan syari'ah melalui jalur demokrasi. Sebagaimana Abdullah Ahmad An-Na im menjelaskan bahwa penerapan hukum Islam harus mendapatkan dukungan publik atau masyarakat. Abdullah Ahmad An-Na im juga tegas menyatan bahwa setiap perundangan dan perturan publik semestnya mereflesikan keyakinan dan nilainilai masyarakat. Inilah yang dikritik oleh Busyro bahwa secara logika bisa ditarik sebuah pemahaman, apabila publik menghendaki penerapan hukum qisahs, hudud, poligami, atau hukum-hukum lain yang dikecam olehnya, seharusnya hukum itu juga dapat diadopsi dan dijadikan peraturan serta hukum publik. Akan tetapi Abdullah Ahmad An-Na im menolak hal yang semacam itu. ${ }^{56}$

Cukup beralasan jika banyaknya anggapan bahwa metode yang disajikan oleh Abdullah Ahmad An-Na im sangat tidak relevan untuk dijadikan sebagai metode istinbath kontemporer. Karena banyaknya kelemahan pemikiran pembaharuan yang diusung oleh Abdullah Ahmad An-Na im dari aspek metodologisnya.

Pertama, ketiadaan metode ataupun teori yang diciptakannya sendiri, maksudnya ia pada dasarnya tidak mengagas sebuah pemikiran baru, melainkan hanya mengadopsi apa yang digagas oleh gurunya. Ia hanya mengelaborasi pandangan gurunya yang kemudian ia membangun sebuah kerangka yang dianggap sebuah metodologi ijtihad modern.

Di samping itu meskipun teori nasakh yang ia elaborasi tersebut dianggap sebagai sebuah alternatif dalam melakukan ijtihad, akan tetapi teori nasakh ini tidak lebih dari rekonstruksi terhadap teori nasakh klasik yang telah dibangun secara sistematis dan komprehensif oleh para ulama klasik. Di sini ia hanya melakukan kajian ulang dengan arti ia tidak memformulasi sebuah metode yang benar-benar baru yang tidak pernah dikenal dalam keilmuan Islam klasik. ${ }^{57}$

Kedua, penulis melihat bahwa adanya pemahaman keliru terhadap konsep nasakh. Di mana argumentasinya yang menjelaskan bahwa antara ayat Madaniyyah dengan ayat Makkiyah telah terjadi proses nasakh (ketika ia menjelaskan konsep nasakh). menurut penulis merupakan pemahaman serta argumentasi yang kurang memiliki validitas yang semestinya.

Ketiga, terkait dengan persoalan ketika Abdullah Ahmad An-Na`im mengkerangka pengkategorian ayat, pemisahan serta pengunggulan antara sebuah ayat dengan ayat yang lain. Ketika ia menjelaskan bahwa ayat Makkiyah lebih memiliki pesan yang substansif universal dan fundamental dan ayat Madaniyyah merupakan ayat-ayat yang memiliki pesan partikular dan penuh deskriminatif. Menurut penulis, pemahaman seperti ini merupakan suatu konklusi yang sangat dipaksakan untuk mendukung metodologi yang dibangunnya.

Keempat, penafsirannya yang radikal tanpa adanya sintesa, ketika Abdullah Ahmad An-Na`im mempertemukan teori atau ayat-ayat Makkah dengan praktik realitas yang kongkrit akan tetapi pembacannya tidak mempu untuk memberikan solusi yang memadai untuk memecahkan persoalan-persoalan lain diluar syari ah historis yang ia kritik dan ia anggap tidak sesuai lagi untuk masyarakat modern.

Kelima, penulis menganggap hal ini adalah persoalan utopia tanpa pergeseran paradigma, karena sebagaimana yang dijelaskan oleh Moh. Dahlan bahwa pemikiran yang dibangun oleh Abdullah Ahmad An-Na im masih bersifat tekstual-reproduktif. Cara penyelesaian yang selalu berbicara justifikasi dan legitimasi atau hanya sekedar mengeluarkan
${ }^{56}$ Busyro. h. 56 Izomiddin, 'Tipologi Pembaharuan Hukum

lam (Syari`ah) Abdullahi Ahmad An-Na`im', Jurnal
Intizar Universitas Islam Negeri Raden Fatah Palembang 20, no. 1 (2014): 101. 
hukum yang berarti bercorak dogmatik atau logic of repeatation, bukan produktif atau post-dogmatic. Abdullah Ahmad An-Na im terlalu mengandalkan pemikiran Thaha yang masih teks-oriented, yaitu hanya sekedar pindah dari satu teks ke teks yang lain, atau dapat dikatakan ia tidak bisa memberi ruang yang luas terhadap akal, dalam arti sulit untuk memahami teks wahyu dalam menjawab isu-isu kekinian.

\section{KESIMPULAN}

Metode yang di sajikan oleh Abdullah Ahmad An-Na im pada kenyataannya belum mampu menjawab situasi dan kondisi aktual saat ini. Karena metodologi yang dibangunya dianggap belum komprehensif dan masih dalam tahap permukaan. Selain itu metode yang ia sajikan hanya mengandalkan teks kebahasaan saja dan di satu sisi terlalu mengagungkan dan menjadi hak asasi manusia sebagai pertimbangan pemberlakuan suatu ayat, sehingga ia tidak bisa menghindar ataupun mencari solusi Islam ketika tidak ada keterangan eksplisit dalam Alquran atau sunnah. Padahal, pembacaan hukum Islam yang hanya mengandalkan teks akan menciptakan suatu sikap yang apologis. 
ALHURRIYAH : Jurnal Hukum Islam
eISSN: 2549-4198

pISSN: 2549-3809
Vol. 05., No. 01. Januari-Juni 2020

\section{DAFTAR KEPUSTAKAAN}

Al-Qattan, Manna`Khalil. Mabahits Fi Ulumil Qur`an. Haramain: [ttp], [tth].

An-Na im, Abdullah Ahmad. Islam And Human Rights; Selected Essay Of Abdullah Ahmad An-Na im, Diedit Oleh Mashood A. Baderin. London And New York: Routledge and Taylor Francis Group, 2016.

- Toward an Islamic Reformation: Civil Liberties, Human Right, and International Law. New York: Syracuse University Press, 1990.

—. Toward an Islamic Reformation; Civil Liberties, Human Right and International Law. Yogyakarta: LKiS, 1994.

An-Na im, Abdullah Ahmad, Mohammed Arkoun, and dkk. Islamic Law Reform And Human Rights Challenges And Rejoinders, Terj. Dekonstruksi Syari ah (II), Diterjemabkan Farid Wajidi. Yogyakarta: LKiS, 1996.

An-Na im, Abdullah Ahmad, terj; Ahmad Suaid dan Amirrudin Arrani. Dekonstruksi Syariah. Yogyakarta: LKIS, 1994.

An-Nawawi, Rifaat Syauqi. Rasionalitas Tafsir Mubammad Abduh, Kajian Masalab Aqidah Dan Ibadat. Jakarta: Paramadina, 2002.

Anwar, Rosihan. Ulum Al-Qur'an. Bandung: Pustaka Setia, 2010.

Bahri, Syamsul. Metodologi Hukum Islam. Yogyakarta: Teras, 2008.

Busyro. 'Abdullah Ahmad An-Na im Dan Pemikiran Liberalisnya'. ALHURRIY AH: Jurnal Hukum Islam (ALHURRIY AH JOURNAL OF ISLAMIC LAW) 15, no. 2 (2014): 55.

Dahlan, Moh. Abdullah Ahmad An-Na im Epistimologi Hukum Islam. Yogyakarta: Pustaka Pelajar, 2009.

Duran, Khalid. 'An Alternatif to Islamism: The Evolutionary Thought of Mahmud Thaha, Cross Currents’. Pro Quest Religion Winter 42 (1992): 453-67.

Fanani, Muhyar. Abdullah Ahmad An-Na im; Paradigma Baru Hukum Publik Islam, Dalam A. Khodri Shaleh, Pemikiran Islam Kontemporer. Yogyakarta: Jendela, 2003.

Hadyianto, Andy. 'Makkiyah Madaniyyah Upaya Rekonstruksi Peristiwa Pewahyuan'. Jurnal Studi Al-Qur'an Universitas Negeri Jakarta 7, no. 1 (2011): 75.

Hakim, Atang Abd., and Jaih Mubarok. Metodologi Studi Islam. Bandung: PT Remaja Rosdakarya, 2000 .

Hanthur, Mahmud Muhammad al-. Nasakh Inda Al-Fakhru Ar-Razৃi. Qahirah: Maktabah al-Adab, 2002. 
https://www.slideshare.net/NabilRahmanElFaqir/abdullah-ahmed-an-naim

Hefni, Muhammad. 'Desakan Sosiopolitik Munculnya Gagasan Evolusi Syari ah Oleh An-Na ‘im'. Al-Abkam 8, no. 1 (2013): 104.

Izomiddin. 'Tipologi Pembaharuan Hukum Islam (Syari ah) Abdullahi Ahmad An-Na im'. Jurnal Intizar Universitas Islam Negeri Raden Fatah Palembang 20, no. 1 (2014): 101.

Jauzi, Ibn al. Nawasikh Al-Qur’an. Madinah: Ihya al-Turats al-Islami, 1984.

Khurzman, Charles, terj. Bahrul Ulum et.al, judul asli: Liberal Islam A Sourcebook. Wacana Islam Liberal Pemikiran Islam Kontemporer Tentang Isu-Isu Global. Jakarta: Paramadina, 2001.

Mutawalli. 'Pembaharuan Hukum Islam Menimbang Pemikiran `Abd Al-Lah Ahmad Al-Na im'. Ulumuna 12, no. 1 (2008): 113.

Nata, Abuddin. Peta Keragaman Pemikiran Islam Di Indonesia. Jakarta: PT Raja Grafindo, 2001.

Raharjo, Dawam. Intelektual Intelegensia Dan Perilaku Politik Bangsa: Risalah Cendikiawan Muslim. Bandung: Mizan, 2008.

Rahman, Fathor. 'Pencarian Format Baru Syari`ah Di Era Modern (Kajian Atas Konsep Reformasi Syari’ah Dalam Dekonstruksi Syariah-Nya Abdullah Ahmed An-Na`im)'. Jurnal Institut Agama Islam Ibrabimy Situbondo 5, no. 1 (2013): 159.

Thaha, Mahmud Muhammad. Syariat Demokratik, Terj. Nur Rachman, Judul Asli: Shariah Demokratik. Surabaya: eLSAD, 1996.

Wijaya, Aksin. Menggugat Otensitas Wabyu Tuban; Kritik Atas Nalar Tafsir Gender. Yogyakarta: Safiria Insania Press, 2004.

Zahrah, Muhammad Abu. Ubsul Figh, Terj. Saifullah Maksum. Jakarta: Pustaka Firdaus, 2008. 